\title{
Spontaneous Speech in Dementia
}

\section{Спонтанная речь при деменции}

\author{
Eda Can \\ Эда Джан \\ Ph.D. in General Linguistics, \\ Lecturer
кандидат филологических наук, преподаватель \\ E-mail: eda.can@deu.edu.tr \\ orcid.org/0000-0002-0061-1843
}

\section{Gülmira Kuruoğlu}

Ph.D. in Linguistics, Professor

\section{Гульмира Куруоглу \\ кандидат филологических наук, профессор}

Email: gulmira.kuruoglu@deu.edu.tr orcid.org/0000-0002-4172-0253

Dokuz Eylul University,

Department of Linguistics

Buca-Izmir, Turkey, 35390
Университет Докуз Ейлул, кафедра лингвистики

Буча-Измир, Турция, 35390

Original manuscript received September 22, 2018

Revised manuscript accepted September 18, 2019

\begin{abstract}
Introduction. Although memory impairment is the main symptom of Alzheimer Disease $(A D)$, language impairment can be an important evidence, too. In many researches, it is stated that language is impaired in a different way in AD. Syntax, which is the subfield of language are more preserved compared to the other fields. However, it is also known that syntactic features of $A D$ patients can also be impaired in the moderate and severe stages of the illness. Another important thing that is important to differentiate the effects of illness is the onset. There are two subtypes of AD: early-onset (befor 65 years old) and late-onset (after 65 yaers old). Compared to late-onset, early onset Alzheimer's Disease (EOAD) is often associated with atypical symptoms including language and visuospatial dysfunction. Thus, in this study it was aimed to analyse the spontaneous speech of EOAD patients via two language tests and compare it with an
\end{abstract}


age/education-matched control. In this analysis, just the declarative and interrogative sentences were compared.

The results show that the number of declarative and interrogative sentences used by the EOAD patients differs from the control people. EOAD patients used more affirmative and interrogative sentences in story-picture sequencing test and more negative sentences in subject-based narration test compared to the control group. However, control group used more negative sentences in story-picture sequencing test and more affirmative and interrogative sentences in subject-based narration test compared to the EOAD patients.

Conclusions. The working memory is the ability to maintain and use information for a short period of time and due to the working memory deficits in EOAD patients, the use of sentence types differ from age/matched healthy people.

Key words: Alzheimer's Disease, early-onset Alzheimer's patients, spontaneous speech Alzheimer's patients, declarative sentences, interrogative sentences.

\section{Introduction}

Dementia is characterized by the breakdown of intellectual and communicative functioning and it is accompanied by personality change (DSM-IV, American Psychiatric Association 1994). Dementia includes a group of symptoms that can be caused by many diseases. These symptoms are mental confusion, memory loss, disorientation or similar problems (Mace and Rabins, 2017). There are different types of dementia that are based on pathophysiology and patterns of neurocognitive impairment that are demonstrative of the neural networks involved (Wischenka, Marquez and Felsted, 2016). Different dementias affect different parts of the brain, but they do not result in obvious brain damage in distinctly localized areas of the brain the way aphasias do. The distinction of cortical and subcortical dementias is crucial. In the cortical dementias, the cellular changes associated with dementia are primarily in cortical areas; in the subcortical ones, the cellular changes are primarily in subcortical structures. The most commonly known cortical dementia is Alzheimer's Disease (AD) (Obler and Gjerlow, 2000).

There are some criteria applied for the diagnosis of the AD. The criteria were specified as: a decline in intellectual abilities (sufficient to interfere with social or occupational functions); memory impairment; and at least one of either impaired abstract thinking, impaired judgement, 
personality change or other disturbance of higher cortical function (e.g. aphasia, apraxia, agnosia or constructional difficulty) (Smith, Chenery \& Murdoch., 1987). The consequences of being diagnosed early with a disease that implies progressive decline of cognitive abilities and activities of daily living performance, as well as changes in personality and behavioral disturbances, are enormous (Bakker et al., 2013). The language of dementing patients presents a unique opportunity for examining the relationship between language and cognition. The pattern of dissociation of abilities in dementia can yield information regarding the normal relationship - dependence or independence - between language and more general cognitive abilities (Obler \& Gjerlow, 2000).

Most descriptions of the clinical and cognitive characteristics of $\mathrm{AD}$ highlight deficits in memory, executive function, reasoning and visuoconstructive abilities and remark on the relative preservation of language skills. Most aspects of language are said to be well preserved until the very late stages of AD (Forbes-McKay \& Venneri, 2005). Although memory impairment is the main symptom of $A D$, language impairment can be an important marker (Fraser, Meltzer \& Rudzicz, 2016).

The symptoms of $\mathrm{AD}$ depend on the stage of the disease. $\mathrm{AD}$ is classified into preclinical, mild, moderate, and late-stage depending on the degree of cognitive impairment. The initial presenting symptom is usually recent memory loss with relative sparing of long-term memory and can be elicited in most patients even when not the presenting symptom. Short-term memory impairment is followed by impairment in problem-solving, judgment, executive functioning, lack of motivation and disorganization, leading to problems with multitasking and abstract thinking. In the early stages, impairment in executive functioning may be subtle. This is followed by language disorder and impairment of visuospatial skills. Neuropsychiatric symptoms like apathy, social withdrawal, disinhibition, agitation, psychosis, and wandering are also common in mid to late stages. Difficulty performing learned motor tasks (dyspraxia), olfactory dysfunction, sleep disturbances, extrapyramidal motor signs like dystonia, akathisia, and parkinsonian symptoms occur late in the disease (Kumar \& Tsao, 2018).

$\mathrm{AD}$ has two subtypes: early onset and late onset. Early onset Alzheimer's disease (EOAD), which is defined as a symptom onset under the age of 65 , represents the most common cause of young 
onset dementia (Harvey et al., 2003). The results in literature regarding the patterns of cognitive dysfunction in EOAD and late onset are not parallel, but considering all these results taken from these studies, it can be said that EOAD patients have more prominent difficulties in non-memory domains which include language, visuospatial skills, and executive functions (Joubert et al., 2016).

EOAD frequently presents in atypical ways and is often poorly assessed and managed (Spreadbury \& Kipps, 2019). It has been reported that the prevalence of EOAD is between 78 and 700 per 100,000 population (Wing $\mathrm{Chi} \mathrm{Au}$ et al., 2019). EOAD differs in the areas of the brain which are targeted, rather than only in the rate of progression. EOAD patients appear to be hit harder in attention-related areas of memory, while the late onset patients appear to have more damage in areas related to recall and recognition (Kensinger, 1996). When the studies related to the language are considered, it can ben seen that several kinds of language functions were described as more severely deteriorated in early rather than late-onset patients. However; in other studies it was reported that there are more profound language dysfunctions in late-onset patients (Immamura et al., 1998).

Patients with EOAD are significantly different in their clinical and neurobiological features and require different management strategies. The clinical profile of EOAD differs from that of late-onset AD. A high proportion of patients with EOAD present with language, visuospatial, or dysexecutive phenotypes rather than the usual amnestic disorder seen in late-onset (Mendez, 2019). The most common presentation of EOAD is with progressive episodic memory impairment-amnestic or typical Alzheimer's disease. However, EOAD is notable for its phenotypic heterogeneity, with posterior cortical atrophy-characterised by prominent higher-order visual processing deficits and relative sparing of episodic memory-the second most common canonical phenotype (Parker et al., 2019). EOAD can be caused by mutations in presenilin 1, presenilin 2 and amyloid precursor protein in an autosomal dominant inheritance pattern (as sited in Wong et al., 2019).

A progressive language decline in language abilities is a widely known clinical indication of $\mathrm{AD}$ and it is said to be as one of the earliest symptom of it. At the beginning, language deficits are not severe; however, these problems become severe during the later stages of $\mathrm{AD}$ (Emery, 2000). 
Speech and language production both require significant levels of neurological function. Therefore, information derived from analyzing speech (the acoustic signal) and language production (words and sentences) serves as a useful window into the health of an individual's cognitive ability (Voletti, Liss \& Berisha, 2019).

The assessment of spontaneous speech appears to offer a more naturalistic assessment of language, which may prove to be a powerful method of assessing individuals with dementia, as well as other dementias (Bucks et al., 2000). Additionally, several more complicated methods for syntactical analysis of natural language can also be used to gain better insight for assessing linguistic complexity and cognitive health (Voletti, Liss \& Berisha, 2019).

Spontaneous speech is a complex source of information encompassing of various hierarchical levels of language organization, and a recent literature review indicated that phonetic, phonological, morpho-syntactic and lexico-semantic levels are to some extent affected in AD (Boschi et al., 2017).

The aim of this study was to reveal the features of spontaneous speech of EOAD patients via two language tests and to compare all the results with an age/education-matched control group that has no neurological and psychological problems.

\section{Materials and Method}

Before this research was conducted, permission was obtained from the Non-Interventional Ethics Committee in Dokuz Eylül University, Faculty of Medicine.

\section{Participants}

In order to decide the sample size of the study, a power analysis was used and 23 EOAD patients (age: 59.86) from Dokuz Eylul University, Faculty of Medicine, Department of Neurology and an age/ education-matched control group (CG) consisting of 26 healthy people (age: 62.88) were included in this study.

\section{Data Collection}

Before the implementation of the language tests, a neurologist and a psychologist made a physical and neurological examination via Mini-Mental State Examination (MMSE; Folstein et al., 1975), Auditory Verbal Learning Test (Rey, 1964) Verbal Fluency Test (VFT) and 
Clinical Dementia Rating. By the help of MMSE, it was found out that all patients with EOAD were in the moderate stage.

\section{Language Tests}

In order to analyse the spontaneous speech of EOAD patients in terms of declarative and interrogative sentence types two picture description tests were used: Story-Picture Sequencing Test and Subjectbased Narration Test. In story-picture sequencing test, EOAD patients and CG were asked to connect different pictures and create a story. In subject-based narration test the examiner asked if they could tell her the happiest or most depressing moment of their lives. It was expected that they would tell their memories via logical sequence of events. By the help of this test, the patients were made to feel more comfortable without visual data and without any restrictions, so that the narrative skills of these patients were revealed more clearly.

Language tests lasted four minutes and all interviews were recorded with a tape recorder and then transcribed based on the DuBois' Discourse Transcription Symbols (1993).

\section{Statistical Analysis}

Statistical Package for the Social Sciences (SPSS) was used for the data analysis. Qui-square test was used for the comparison of the sentence types within groups (EOAD-CG) and median test was used to reveal if the difference between these groups was statistically significant.

\section{Results}

First of all, two groups were compared in terms of age, gender, education level and MMSE mean scores and it was revealed that there was no statistically significant difference between the two groups in terms of these variables except for MMSE ( $>0.0292 / \mathrm{p}>0.0309 /$ $\mathrm{p}>0.0469 / \mathrm{p}<0.005)$.

Table 1. Comparisons of demographic and clinical variables in both groups: EOAD and $\mathrm{CG}$

\begin{tabular}{lccc}
\hline & EOAD $(\mathbf{n}=\mathbf{2 3})$ & CG $(\mathbf{n}=\mathbf{2 6})$ & $\mathbf{p}$ \\
\hline Age & 59.86 & 62.88 & 0.292 \\
Education & 5 & 15 & 0.309 \\
Gender & $\bigcirc$ & 14 & 0.469 \\
MMSE & 10 & 30 & 0.005 \\
\hline
\end{tabular}


After revealing that these two groups are suitable for the comparison, spontaneous speech of EOAD patients and CG were compared in terms of declarative and interrogative sentences.

Table 2. Comparisons of declarative and interrogative sentences

\begin{tabular}{lcccccc}
\hline Language Tests & N & Group & $\begin{array}{c}\text { Affirmative } \\
\mathbf{f ~ ( \% )}\end{array}$ & $\begin{array}{c}\text { Negative } \\
\mathbf{f ~ ( \% )}\end{array}$ & $\begin{array}{c}\text { Interrogative } \\
\mathbf{f}(\mathbf{\%})\end{array}$ & $\mathbf{p}$ \\
\hline Story-Picture & 26 & CG & 84.3 & 13.7 & 2 & $\mathbf{0 . 0 0 0}$ \\
Sequencing Test & 23 & EOAD & 87.9 & 4.7 & 7.5 & \\
Subject-based & 26 & CG & 93.9 & 5.3 & 8 & $\mathbf{0 . 0 3 0}$ \\
Narration Test & 23 & EOAD & 87.2 & 9 & 3.7 & \\
\hline
\end{tabular}

As seen in table 2, in both tests there was a statistically significant difference between the use of sentence types. Both EOAD patients and CG used more affirmative sentences compared to the negative and interrogative sentence types in story-picture sequencing test and subjectbased narration test. However, in story-picture sequencing test EOAD patients used interrogative sentences more compared to the negative sentences whereas CG used negative sentences more compared to the interrogative sentences.

In subject-based narration test, EOAD patients used negative sentences more compared to the interrogative sentences whereas CG used interrogative sentences more compared to the negative sentences.

Table 3. Findings related with median test

\begin{tabular}{|c|c|c|c|c|c|}
\hline Language Tests & $\mathbf{N}$ & Group & $\begin{array}{c}\text { Affirmative } \\
\mathbf{p}\end{array}$ & $\begin{array}{c}\text { Negative } \\
\text { p }\end{array}$ & $\begin{array}{c}\text { Interrogative } \\
\text { p }\end{array}$ \\
\hline $\begin{array}{l}\text { Story-Picture } \\
\text { Sequencing Test }\end{array}$ & $\begin{array}{l}26 \\
23\end{array}$ & $\begin{array}{c}\text { CG } \\
\text { EAOD }\end{array}$ & 0.000 & 0.045 & 0.005 \\
\hline $\begin{array}{l}\text { Subject-based } \\
\text { Narration Test }\end{array}$ & $\begin{array}{l}26 \\
23\end{array}$ & $\begin{array}{c}\text { CG } \\
\text { EAOD }\end{array}$ & 0.002 & 0.022 & 0.011 \\
\hline
\end{tabular}

In story-picture sequencing test, there was a statistically significant difference between EOAD and CG in terms of the use of affirmative, negative and interrogative sentences. Considering the number of sentences, EOAD patients used more affirmative and interrogative sentences than the CG.

In subject-based narration test, there was a statistically significant difference between EOAD and CG in terms of the use of affirmative, 
negative and interrogative sentences. Considering the number of sentences, EOAD patients used more negative sentences than the CG.

Table 4. Comparison of declarative and interrogative sentences within tests

\begin{tabular}{lccccc}
\hline $\begin{array}{l}\text { Sentence } \\
\text { Types }\end{array}$ & Group & $\mathbf{N}$ & $\begin{array}{c}\text { Story-Picture } \\
\text { Sequencing Test } \\
\mathbf{f}(\%)\end{array}$ & $\begin{array}{c}\text { Subject-based } \\
\text { Narration Test } \\
\mathbf{f ~ ( \% )}\end{array}$ & P \\
\hline \multirow{2}{*}{ Affirmative } & CG & 26 & 26.6 & 24.7 & 0.000 \\
\multirow{2}{*}{ Negative } & EOAD & 23 & 34.6 & 30.2 & 0.000 \\
& CG & 26 & 50 & 16.3 & 0.000 \\
Interrogative & EOAD & 23 & 19.2 & 32.7 & 0.000 \\
& CG & 26 & 26.1 & 8.7 & 0.000 \\
& EOAD & 23 & 22.2 & 9.7 & 0.000 \\
\hline
\end{tabular}

According to the results shown in table 4, there was a statistically significant difference within tests. EOAD patients produced more affirmative and interrogative sentences in story-picture sequencing test whereas they produced more negative sentences in subject-based narration test. Considering the results of $\mathrm{CG}$, it was revealed that they produced more affirmative, negative and interrogative sentences in storypicture sequencing test compared to the subject-based narration test.

\section{Discussion}

Evaluation of spontaneous speech is a closer approximate of realworld use of language, with high ecological validity and potentially higher sensitivity to subtle language deficits (Verfaillie et al., 2019). In this context, the spontaneous speech of EOAD patients was analysed by using two language tests in terms of declarative and interrogative sentence types in this study. The results show that the number of declarative and interrogative sentences used by the EOAD patients differs from the age/education matched people. EOAD patients used more affirmative sentences compared to the negative and interrogative sentence types in story-picture sequencing test and subject-based narration test. With regard to the interrogative sentence, EOAD patients used more interrogative sentences compared to the negative sentences not only in story-picture sequencing test but also in subject-based narration test. When the comparison of tests are considered, it can be 
understood that EOAD patients had negative aspects in subject-based narration test. In this test, EOAD patients were asked to talk about a happy or unhappy memory. Due to their psychological situation, they always talked about the things that made them upset. In story-picture sequencing test EOAD patients used interrogative sentences more. In this test, they were asked to make a connection between pictures and tell a story. However, due to their working memory deficits, they had problems in making connection. As it is stated in many researches, the working memory is the ability to maintain and use information for a short period of time.

In the first studies about the cognitive presentation of symptoms, it was revealed that EOAD patients had worse performances in language and visuospatial tests. Other studies have also shown that age onset also made a difference in cognitive profile of AD (Palasi et. al., 2015). Some researches about speech production suggests that lexical selection during speech production takes place in the left (posterior) middle temporal gyrus. Others have suggested that semantic processing disturbance in AD is secondary to a working memory deficit, resulting in the production of more general ('empty') speech (Verfaillie et. al., 2019).

In literature, there are no studies related with declarative and interrogative sentences. There are considerably few studies which are about the perception of vocabularies as positive, negative and neutral. In one of these studies, $A D$ patients were asked to classify the words shown from the computer as positive, negative or neutral. Results show that patients with AD performed well in positive words compared to negative words (Phelps et. al., 1997). Kensinger et. al., (2002) also studied the perception of pictures as positive, negative or neutral in $\mathrm{AD}$ patients and the relation with the sensory memory. It was found that $\mathrm{AD}$ patients did not have too much difficulty in labeling the words or pictures as positive, negative or neutral. However, their performance was worse compared to the healthy people.

In literature, most studies are related with the performance of EOAD patients' language performance are about the complex sentences, simple sentences and the other syntactic features. For example, Kemper et al. (2001) stated that aging would cause differences in linguistic aspects on individuals. In their study, they found out that there was a similar change for the production of the sentences. It was suggested that complex sentence production decreases with age and 
individuals tended to use simple structures. In another study, Kertesz (2004) stated that syntactic structures were protected in the early stages of $\mathrm{AD}$ disease, and in later stages, they they experienced problems in the production of sentences. It is also stated that syntactic disorders were more related to EOAD patients. Can \& Kuruoglu (2017, 2018a) found out that the sentence length of EOAD patients was lower than the control group and late-onset. In another study, it was found out that cognitive deficits made EOAD patients performed worse in different language tests and it was also revealed that there was no tendency to use coordinated and compound sentences in their speeches (Can \& Kuruoglu, 2018b).

There are several studies supporting that in spontaneous speech, the degree of lexical complexity and content words are impaired in $\mathrm{AD}$, whereas syntactic complexity is affected only until later stages (Kemper et al., 1994, 2001; Emery, 2000; Gayraud et al., 2011; Roark et al., 2011; Ahmed et al., 2013; Fraser et al., 2015). In our study, all patients were in the moderate stage. The use of the declarative and interrogative sentences were different from the healthy subjects. Within the tests, the use of sentence types changed related with the perception of EOAD patients.

To conclude, in this study the spontaneous speech of EOAD patients in terms of the sentence types (declarative and interrogative sentences) revealed that they produced affirmative and interrogative sentences more in story-picture sequencing test. It is believed that due to be hit harder in attention-related areas of memory, a deficit in visual perception or object identification, EOAD patients' sentence production was different in picture description tests. EOAD patients tended to use interrogative sentences to clarify their perception. The use of negative sentences was much higher in subject-narration test. In this test, they were asked to tell a memory, but again it is believed that due to their psychological condition they tended to tell a negative memory. Thus, they used negative sentences more compared to the other sentence types.

\section{References}

Ahmed, S., Haigh, A.-M.F., de Jager, C.A., \& Garrard, P. (2013). Connected speech as a marker of disease progression in autopsy-proven Alzheimer's disease. Brain, 136, 3727-3737. https://doi.org/10.1093/brain/awt269 
American Psychiatric Association. (1994). Diagnostic and Statistical Manual of Mental Disorders. Washington DC: American Psychiatric Assocciation.

Bakker, C., de Vugt, M.E., van Vliet, D., Verhey, F.R., Pijnenburg, Y.A., VernooijDassen, M.J., \& Koopmans, R.T. (2013). The use of formal and informal care in early onset dementia: results from the NeedYD study. The American Journal of Geriatric Psychiatry, 21(1), 37-45. https://doi.org/10.1016/j.jagp.2012.10.004

Boschi, V., Catricala, E., Consonni, M., Chesi, C., Moro, A., \& Cappa, S.F. (2017). Connected speech in neurodegenerative language disorders: a review. Frontiers in psychology, 8, 269. https://doi.org/10.3389/fpsyg.2017.00269.

Bucks, R.S., Singh, S., Cuerden, J.M., \& Wilcock, G.K. (2000). Analysis of spontaneous, conversational speech in dementia of Alzheimer type: Evaluation of an objective technique for analysing lexical performance. Aphasiology, 14(1), 71-91. https://doi.org/10.1080/026870300401603

Can, E., \& Kuruoglu, G. (2017). Sentence Length of Turkish Patients with Early and Late-Onset Alzheimer's Disease. Humanities and Social Sciences Review, 06(02), 69-78.

Can, E., \& Kuruoglu, G. (2018a). A comparison of Sentence Production of Turkish Patients with Early and Late-Onset Alzheimer's Disease. International Journal of Psycho-Educational Sciences, 7(1).

Can, E., \& Kuruoglu, G. (2018b). Assessment of Syntactic Complexity in Alzheimer's Disease. Proceedings Book of Eurasian Conference on Language and Social Science (pp. 539-549). Antalya.

Du Bois, J.W., Schuetze-Coburn, S., Cumming, S., \& Paolino, D. (1993). Outline of discourse transcription. In Jane A. Edwards \& Martin D. Lampert (Eds.), Talking Data: Transcription and coding in discourse research, (pp. 45-89). New York: Psychology Press.

Emery, V.O. (2000). Language impairment in dementia of the Alzheimer type: a hierarchical decline? Int. J. Psychiatry Med, 30, 145-164. https://doi.org/10.2190/ X09P-N7AU-UCHA-VW08

Folstein, M.F., Folstein, S.E., \& McHugh, P.R. (1975). Mini-Mental State. A practical method for grading the cognitive state of patients for the clinician. Journal of Psychiatric Research, 12, 189-198. https://doi.org/10.1016/0022-3956(75)90026-6

Fraser, K.C., Meltzer, J.A., \& Rudzicz, F. (2016). Linguistic features identify Alzheimer's disease in narrative speech. Journal of Alzheimer's Disease, 49(2), 407-422. https://doi.org/10.3233/JAD-150520

Fraser, K.C., Ben-David, N., Hirst, G., Graham, N., \& Rochon, E. (2015). Sentence segmentation of aphasic speech. In Proceedings of the 2015 Conference of the North American Chapter of the Association for Computational Linguistics: Human Language Technologies (pp. 862-871). https://doi.org/10.3115/v1/N15-1087

Forbes-McKay, K.E., \& Venneri, A. (2005). Detecting subtle spontaneous language decline in early Alzheimer's disease with a picture description task. Neurological sciences, 26(4), 243-254. https://doi.org/10.1007/s10072-005-0467-9

Gayraud, F., Lee, H., \& Barkat-Defradas, M. (2011). Syntactic and lexical context of pauses and hesitations in the discourse of Alzheimer patients and healthy elderly subjects. Clin. Linguist. Phon, 25, 198-209. https://doi.org/10.3109/02699206.20 10.521612

Harvey, R.J., Skelton-Robinson, M., \& Rossor, M.N. (2003). The prevalence and causes of dementia in people under the age of 65 years. Neurol. Neurosurg. Psychiatry, 74, 1206-1209. https://doi.org/10.1136/jnnp.74.9.1206 
Imamura, T., Takatsuki, Y., Fujimori, M., Hirono, N., Ikejiri, Y., Shimomura, T., Yamashita, Y., \& Mori, E. (1998). Age at onset and language disturbances in Alzheimer's disease. Neuropsychologia, 36(9), 945-949. https://doi.org/10.1016/ S0028-3932(98)00010-4

Joubert, S., Gour, N., Guedj, E., Didic, M., Guériot, C., Koric, L., Ranjeva, J., Felician, O., Guye, M., \& Ceccaldi, M. (2016). Early-onset and late-onset Alzheimer's disease are associated with distinct patterns of memory impairment. Cortex, 74, 217-232. https://doi.org/10.1016/j.cortex.2015.10.014

Kemper, S., Anagnopoulos, C., Lyons, K., \& Heberlein, W. (1994). Speech accommodations to dementia. Gerontol, 49, 223-229. https://doi.org/10.1093/ geronj/49.5.P223

Kemper, S., Greiner, L.H., Marquis, J.G., Prenovost, K., \& Mitzner, T. (2001). Language Decline Across the Life Span: Findings from the Nun Study. Psychology and Aging, 16, 227-239. https://doi.org/10.1037/0882-7974.16.2.227

Kensinger, E. (1996). Early and late onset as subdivisions of Alzheimer's disease (pp. 26-36). Harvard Brain.

Kensinger, E.A., Brierley, B., Medford, N., Growdon, J.H., \& ve Corkin, S. (2002). Effects of normal aging and Alzheimer's disease on emotional memory. Emotion, 2(2), 118-134. https://doi.org/10.1037/1528-3542.2.2.118

Kertesz, A. (2004). Language in Alzheimer's Disease. Cognitive Neuropsychology of Alzheimer's Disease (pp. 199-263). Editors: Robin Morris and James Becker. USA: Oxford University Press.

Kumar, A., \& Tsao, J.W. (2018). Alzheimer Disease. In StatPearls [Internet]. StatPearls Publishing.

Mace, N.L. and Rabins, P.V. (2017). The 36-Hour Day: A Family Guide to Caring for People Who Have Alzheimer Disease, Other Dementias, and Memory Loss. USA: John Hopkins University Press.

Mendez, M.F. (2019). Early-onset Alzheimer disease and its variants. Continuum (Minneapolis, Minn.), 25(1), 34. https://doi.org/10.1212/CON.0000000000000687

Obler, L.K., \& Gjerlow, K. (2000). Language and the Brain. Cambridge University Press.

Palasí, A., Gutiérrez-Iglesias, B., Alegret, M., Pujadas, F., Olabarrieta, M., Liébana, D., ... \& Boada, M. (2015). Differentiated clinical presentation of early and late-onset Alzheimer's disease: is 65 years of age providing a reliable threshold? Journal of neurology, 262(5), 1238-1246. https://doi.org/10.1007/ s00415-015-7698-3

Parker, T.D., $\quad$ Slattery, C.F., $\quad$ Yong, K.X., $\quad$ Nicholas, J.M., $\quad$ Paterson, R.W., Foulkes, A.J., ... \& Fox, N.C. (2019). Differences in hippocampal subfield volume are seen in phenotypic variants of early onset Alzheimer's disease. NeuroImage: Clinical, 21, 101632. https://doi.org/10.1016/j.nicl.2018.101632

Phelps, E.A., LaBar, K.S., \& ve Spencer, D.D. (1997). Memory for emotional words following unilateral temporal lobectomy. Brain and cognition, 35(1), 85-109. https://doi.org/10.1006/brcg.1997.0929

Rey, A. (1964). L 'examen clinique en psychologie [Clinical tests in psychology]. Paris: Presses Universitaires de France.

Roark, B., Mitchell, M., Hosom, J.P., Hollingshead, K., \& Kaye, J., (2011). Spoken language derived measures for detecting mild cognitive impairment. IEEE Trans. Audio Speech Lang. Process, 19, 2081-2090. https://doi.org/10.1109/ TASL.2011.2112351 
Smith, S.R., Chenery, H.J., \& Murdoch, B.E. (1987). Language disorders associated with dementia of Alzheimer type: A review. Australian Journal of Human Communication Disorders, 15(1), 49-70. https://doi.org/10.3109/asl2.1987.15. issue- 1.05

Spreadbury, J.H., \& Kipps, C.M. (2019). Measuring younger onset dementia: A comprehensive literature search of the quantitative psychosocial research. Dementia, 18(1), 135-156. https://doi.org/10.1177/1471301216661427

Verfaillie, S.C., Witteman, J., Slot, R.E., Pruis, I., Vermaat, L.E., Prins, N.D., .. \& van der Flier, W.M. (2019). High amyloid burden is associated with fewer specific words during spontaneous speech in individuals with subjective cognitive decline. Neuropsychologia. https://doi.org/10.1016/j.neuropsychologia.2019.05.006

Voleti, R., Liss, J.M., \& Berisha, V. (2019). A Review of Language and Speech Features for Cognitive-Linguistic Assessment. arXiv preprint arXiv: 1906.01157.

Wing Chi Au, L., Wong, A., Abrigo, J., Yuen, Y.P., Yim Lung Leung, E., \& Chung Tong Mok, V. (2019). Early-onset dementia in Chinese: Demographic and etiologic characteristics. Neurology Asia, 24(2).

Wischenka, D.M., Marquez, C. and Felsted, K.F. (2016). Geriontology and Geriatrics. New York: Springer.

Wong, T.H., Seelaar, H., Melhem, S., Rozemuller, A.J., \& van Swieten, J.C. (2019). Genetic screening in early-onset Alzheimer's disease identified three novel presenilin mutations. Neurobiology of Aging. https://doi.org/10.1016/j. neurobiolaging.2019.01.015

\begin{abstract}
АННОТАЦИЯ
Введение. Хотя нарушение памяти является основным симптомом болезни Альцгеймера (БА), языковые нарушения также могут быть важным сиптомом болезни. Многие исследования показывают, что язык по-разному нарушается при БА. Синтаксис является более сохранным по сравнению с другими уровням языка. Однако также известно, что синтаксические особенности пациентов с БА могут нарушаться на средней и тяжелой стадиях заболевания. Для дирореренциации последствий болезни важно знать тип БА с точки зрения начала заболевания. Существует два подтипа БА: раннее начало (до 65 лет) и позднее начало (после 65 лет). По сравнению с поздним началом (ПНБА), раннее начало болезни Альцгеймера (РНБА) часто ассоциируется с атипичными симптомами, включая языковую и зрительно-пространственную дисфункцию. Таким образом, в данном исследовании была поставлена цель проанализировать спонтанную речь пациентов с РНБА с помощью двух языковых тестов и сравнить результаты с результатами контрольной группы, идентифицированной по возрасту и образованию с группой БА. В этом анализе было сопоставлено употребление утвердительных и вопросительных предложений.
\end{abstract}

Результаты показывают, что количество употребляемых утвердительных и вопросительных предложений, используемых пациентами РНБА, отличается om количества употребления контрольной группы. Пациенты РНБА по сравнению с контрольной группой использовали больще утвердительных, чем 
отрицательных и вопросительных предложений в тесте по составлению рассказа по картинкам и в тесте повествовании. Пациенты с РНБА использовали больше утвердительных и вопросительных предложений в тесте по составлению рассказа по картинкам и больше отрицательных предложений в тесте повествования. Контрольная группа же использовала больше отрицательных предложений в первом тесте и больше утвердительных и вопросительных предложений во втором тесте.

Выводы. Рабочая память, задача которой сохранять и использовать информацию в течение короткого периода времени, бывает нарушена при РНБА, что и приводит к изменениям в синтаксисе речи больных.

Ключевые слова: болезнь Альцгеймера, раннее начало болезни Алцгеймера, спонтанная речь больных Алцгеймера, утвердительные предложения, вопросительные предложения.

\section{Джан Еда, Куруоглу Гульміра. Спонтанне мовлення при деменції}

\section{АНОТАЦІЯ}

Вступ. Хоча порушення пам'яті є основним симптомом хвороби Альцгеймера (ХА), мовні порушення також можуть бути важливим симптомом хвороби. Численні дослідження показують, що мова по-різному порушується при ХА. Синтаксис $\epsilon$ найбільш збереженим порівняно з іншими рівнями мови. Проте також відомо, що синтаксичні особливості хворих на бронхіальну астму можуть порушуватися на середній $і$ тяжкій стадіях захворювання. Для диреренціації наслідків хвороби важливо знати тип ХА з точки зору початку захворювання. Існує два підтипи ХА: ранній початок (до 65 років) $і$ пізній початок (після 65 років). Порівняно з пізнім початком (ППХА), ранній початок хвороби Альцгеймера (РПХА) часто асоціюється з атиповими симптомами, включаючи мовну й зорово-просторову дисфункцію. Таким чином, у даному дослідженні було сформульовано мету - проаналізувати спонтанне мовлення пацієнтів з РПХА за допомогою двох мовних тестів і порівняти результати з результатами контрольної групи, ідентифікованою за віком і освітою $з$ групою ХА. У цьому аналізі було зіставлене вживання стверджувальних $i$ питальних речень.

Результати. Кількість уживаних стверджувальних і питальних речень, використовуваних пацієнтами РПХА, відрізняється від кількості вживання пацієнтами контрольної групи. Пацієнти РПХА в порівнянні з контрольною групою використовували більше стверджувальних, ніж негативних і питальних речень в тесті на складання розповіді за картинками і в тесті на побудову оповідання. Пацієнти з РПХА використовували більше стверджувальних і питальних речень в тесті на складання розповіді за картинками і більше негативних речень в тесті на складання оповідання. Пацієнти контрольної групи використовували більше негативних речень в першому тесті і більше стверджувальних і питальних речень у другому тесті. 
Висновки. Робоча пам'ять, завдання якої зберігати й використовувати інформацію протягом короткого періоду часу, буває порушеною при РПХА, що й призводить до змін у синтаксисі мови хворих.

Ключові слова: хвороба Альцгеймера, ранній початок хвороби Альцгеймера, спонтанне мовлення хворих на Альцгеймера, позитивні речення, питальні речення. 